\title{
The Correlation between Genital Hygiene and Pathological White Discharge on Students at Vocational High School
}

\author{
$1^{\text {st }}$ Anies Muzayyanatul 'A \\ Midwifery \\ Universitas Ngudi Waluyo \\ Ungaran, Semarangj \\ gunawanprio@gmail.com
}

\author{
$2^{\text {nd }}$ Erlinda Ratih Wulan \\ Public Health Magister Program: \\ Universitas Negri Semarang \\ Semarang, Central Java \\ erlindaratihwulanhapsari31@gmail.com
}

\author{
$3^{\text {rd }}$ Puput Ediyarsari \\ Public Health Magister Program \\ University Negri Semarang \\ Semarang, Central Java \\ puput.ediyarsari@yahoo.com
}

\begin{abstract}
One of the factors that can cause pathological vaginal discharge is Genital hygiene that is not true. This study aims to determine the Genital Relationship Hygiene with Pathological Whitishes to the students in SMK this research is cross sectional with the number of samples of 86 female students were taken by purposive sampling method. Univariate analysis with frequency distribution and bivariate analysis using Chi square test statistic. Univariate analysis tests obtained that most of the respondents had not good genital hygiene behavior as many as 74 students $(87 \%)$ and had pathological white discharge as many as 62 students (72.1\%). Bivariat analysis test using Chi square obtained $p$-value $=0.000$, so that there was a correlation between genital hygiene and pathological white discharge. There was a correlation between genital hygiene and pathological white discharge.
\end{abstract}

Keywords-genital hygiene, pathological white discharge

\section{INTRODUCTION}

Every woman will normally secrete a small amount of vaginal fluid, which is clear. If this discharge does not cause itching, or does not smell bad, this is not a problem ..$^{[33]}$ Bacterial vaginosis is a major cause of pathological whiteness, with a prevalence of up to $48 \%$. In various populations worldwide Bacterial vaginosis is seen in women without sexually active symptoms of 9-50.9\%, in pregnant women 4.9$52 \%$, and in adolescents $13-31.9 \%$. ${ }^{[11]}$

The untreated pathological bleeding effect for adolescents will continue throughout pregnancy, childbirth and childbirth. Whitish is a sign or symptom of a female reproductive tract infection that can have serious repercussions. Untreated leucorrhea other than getting worse if left will spread to the internal organs. Pathological infection or whiteness on the outside of it on an ongoing basis can lead to the abdominal space in the form of wall-covering infections (peritonitis).$^{[13]}$

\section{MATERIALS AND METHODS}

\section{A. Pesantren Community}

Pondok Pesantren is an Islamic educational institution with boarding school system, thus forming a separate community whose members consist of the students, teachers or ustadz and family caretaker pesantren. Given the number of santri, certainly not impossible some of them there are less aware of the importance of health. Therefore it is not surprising that a disease will quickly spread to members of the pesantren community. Therefore every member of the pesantren community needs to know and understand health problems, both to maintain individual health and health together. Adolescent reproductive health is determined by how the teen is in caring for and maintaining the cleanliness of his genital devices . ${ }^{[14]}$

\section{B. Whitish Effects}

The untreated pathological bleeding effect for adolescents will continue throughout pregnancy, childbirth and childbirth. Whitish is a sign or symptom of a female reproductive tract infection that can have serious repercussions. Untreated leucorrhea other than getting worse if left will spread to the internal organs. Pathological infection or whiteness on the outside of it on an ongoing basis can lead to the abdominal space in the form of wall-covering infections (peritonitis) ${ }^{[13]}$

This study uses correlation study method with cross sectional approach, conducted in SMK (Sekolah Menengah Kejuruan) Askhabul Kahfi Gunungpati Semarang 5 and 6 August 2016. The population in this study is all students of SMK Askhabul Kahfi as many as 86 female students, samples taken are 86 students. Sampling techniques used is purposive sampling. This research uses questionnaires collection tool. The analysis used is univariate analysis with frequency distribution and bivariate analysis using Chi square test statistic. 


\section{RESULT AND DISCUSSION}

\section{TABLE 1. FREQUENCY DISTRIBUTION INDEX}

\begin{tabular}{|l|l|c|c|}
\hline \multirow{2}{*}{ Table } & \multicolumn{3}{|c|}{ Table Column Head } \\
\cline { 2 - 4 } Head & \multicolumn{1}{|c|}{ Genital Hygiene } & Frekuensi & Percentage \\
\hline 1 & Not hygiene & 74 & 86 \\
2 & Hygiene & 12 & 14 \\
\hline
\end{tabular}

Based on table 1 above, it can be seen that Genital hygiene at SMK AskhabulKahfiGunungpati Year 2016, from 86 female students, there are 74 students $(86 \%)$, which is bigger than the students who has hygiene only 12 students $(14 \%)$.

TABLE 2. EXPERIENCE IN VAGINAL DISCHARGE, THIS CONDITION SERVES TO CLEAN

\begin{tabular}{llcc}
\hline \multirow{2}{*}{ No } & \multicolumn{3}{c}{ Table frecuency Distribusi of Patological } \\
\cline { 2 - 4 } & Genital Hygiene & $\begin{array}{c}\text { Frekue } \\
\text { nsi }\end{array}$ & $\begin{array}{c}\text { Percenta } \\
\text { ge }\end{array}$ \\
\hline 1 & Experience & 62 & 72,1 \\
2 & Not experience & 24 & 27,9 \\
\hline
\end{tabular}

Based on table 2 above, it can be seen that most of the students at SMK Askhabul Kahfi Gunungpati Year 2016 experience pathological vaginal discharge, totally 62 students $(72.1 \%)$.

TABLE 3. EXPERIENCE IN VAGINAL DISCHARGE. THIS CONDITION SERVES TO CLEAN

\begin{tabular}{llcc}
\hline \multirow{2}{*}{$\begin{array}{c}\text { Genital } \\
\text { hygene }\end{array}$} & \multicolumn{3}{c}{ Pathological vaginal discharge } \\
\cline { 2 - 4 } & Experience & $\begin{array}{c}\text { Not } \\
\text { experience }\end{array}$ & Total \\
\hline No hygiene & 59 & 15 & 74 \\
Hygiene & 3 & 9 & 12 \\
& & & \\
\hline
\end{tabular}

Based on table 3, from the total respondents of 86 female students who do Genital hygiene with no hygiene experience in pathologicalvaginal dischargetotally 59 students (79.7\%), but from those who do Genital hygiene with no hygiene there is no pathological vaginal discharge totally 15 students $(20,3 \%)$, then the students who do Genital hygiene with hygiene from 12 female students there are 3 female students (25\%) who experienced pathological vaginal discharge and the rest do not experience in pathological vaginal dischargetotally 9 female students $(75 \%)$.

\section{Discusion}

Genital hygienein most of the student at SMK AskhabulKahfinot hygiene, from 74 students who are not hygiene 52 students $(60.5 \%)$ clean the genitals after defecating from the back to the front or from the anus to the vagina and only some of them who clean the vagina to the anus of 34 female students (39.5\%). It seems like of a large number of the female students clean the rest of defecating movements from the anus to the vagina may be because they do not know that washing the genital from the anus to the vagina is wrong, this is due to the lack of information they get about Genital hygiene, otherwise they are unlikely to notice from which direction to wash the vagina, they clean the dirty part firstly to the clean area, whereas there are a lot of bacteria in the rectum, which can carry into the vagina and can cause problems that is pathological vagina discharge

The result of the research shows that from 86 respondents, there are 62 female students $(72.1 \%)$, while those who do not have pathological vaginal discharge were only 24 students (27.9\%).

Based on the research data above there are only a small proportion of respondents who do not experience pathological vaginal discharge which means that the students experience in physiologic vaginal dischargein total 24 female students (27.9\%). This is because physiological vaginal discharge is a normal one experienced by every woman in her menstruation cycle. Certainty, all of the women have and protect the vagina from the infection. Pregnant women will also usually experience in vaginal discharge related to the pregnancy. When someone experience in vaginal discharge, one will remove mucus from her vagina. Mucus produced by the cervix and glands in the vagina will come out with dead cells and bacteria.

Normally, every woman will secrete little fluid from vaginal, which is clear. If the discharge of this fluid does not cause itching, or does not smell bad, this is not bea problem [33]. The defense system of the female genitals is quite good, starting from the base acid. Another defense with mucus expenditure that always flows outwards causes the bacteria to be removed and in the form of menstruation. Normal or physiological vaginal discharge can occur in the period leading up to and after menstruation, around the phase of secretion between the day of 10-16 menstruation, also it occurs through the sexual stimulation ${ }^{[13]}$.

Based on table 4.3, of total respondents are 86 students who do Genital hygiene with no hygiene experience in pathology vaginal dischargein total 59 female students $(79,7)$. The results also show the students who Genital hygiene performed with hygiene of 12 female students who did not experience pathological vaginal discharge totally 9 female students $(75 \%)$. This is because someone who does genetal hygiene well will avoid pathological vaginal discharge. Reproductive health of the teenager is determined by how the teenager is in caring for and maintaining the cleanliness of his genital devices. Female teenagers are more susceptible to genital infections if they do not keep their genitalia clean because the vaginal organs are located close to the rectum

\section{CONCLUSION}

Based on the results of research on Genital Hygiene Relationship with Whitish Pathology at the students at SMK Askhabul Kahfi Gunungpati Semarang Year 2016, it can be drawn conclusion. There is a relationship between genital hygiene with pathology whiteness at schoolgirls at SMK Askhabul Kahfi Gunungpati Semarang Year 2016 with p-value $0.000(\mathrm{p}<\alpha=0,05), \mathrm{OR}=11,800$ mean student who Genital hygiennya not hygiene have risk 11,8 times higher experienced pathological pathology compared to hygiene schoolgirls 


\section{REFERENCE}

[1] Cavendish M. 2010. Encyclopedia of Health, Fourth Edition. The Rosen Publishing Group, New York.

[2] Cidadapi E. 2016. Ramuan Herbal ala Thibun Nabawi, Mengupas pengobatan herbal di dalam Thibun Nabawi. Putra Ayu.

[3] Dwikarya M. 2006. Menjaga Organ Intim (Penyakit dan Penanggulangannya). Kawan pustaka, Jakarta.

[4] Efendi F; Makhfudli. 2009. Keperawatan Kesehatan Komunitas Teori dan Praktik dalam Keperawatan. Salemba Medika, Jakarta.

[5] Geyer N; Mogotlane S; Young A. 2009. Juta's manual of nursing, Volume 1 Second Edition. Juta and Company Ltd, Lansdowne.

[6] Gunarsa SD dan Yulia SDG . 2008. Psikologi Perkembangan Anak dan Remaja. BPK Gunung Mulia, Jakarta..

[7] Handayani L; Suharmiati; Atika A. 2012. Menaklukan Kanker Serviks dan Kanker Payudara dengan Tiga Terapi Alami. PT Agro Media Pustaka, Jakarta.

[8] Izhar. 2015. The Blue Book Latest Edition 2015. Izhar Coc.

[9] Kasdu D. 2008. Solusi Problem Wanita Dewasa. Puspa Swara, Jakarta.

[10] Kumar B and Gupta S. 2014. Sexually Transmitted Infections, Second Edition. Elsevier Health Sciences, India.

[11] Manuaba IAC; Ida BGFM; Ida BGM. 2009. Memahami Kesehatan Reproduksi Wanita, Edisi 2. Penerbit Buku kedokteran EGC, Jakarta.

[12] Manuaba IBG. 2010. Ilmu Kebidanan, Penyakit Kandungan dan Keluarga Berencana untuk Pendidikan Bidan. Penerbit Buku Kedokteran EGC, Jakarta.

[13] Marmi. 2014. Kesehatan Reproduksi. Pustaka Pelajar, Yogyakarta.

[14] Maulana HDJ. 2009. Promosi Kesehatan. Penerbit Buku Kedokteran EGC, Jakarta

[15] Milady. 2010. Milady's Standard Professional Barbring, 5 Ed. Cengenge Learning, USA.

[16] Nadesul H. 2009. Kiat Sehat Pranikah, Menjadi Calon Ibu, Membesarkan Bayi dan Membangun Keluarga Muda. Kompas, Jakarta.

[17] Nadesul H. 2010. Cara Sehat Cantik-Feminim-Cerdas Menjadi Perempuan. Kompas, Jakarta.
[18] Noor J. 2011. Metodologi Penelitian: Skripsi, Tesis, Disertasi, dan Karya Ilmiah. Kencana, Jakarta.

[19] Notoatmodjo S. 2010. Metodologi Penelitian Kesehatan. Rineka Cipta, Jakarta.

[20] Pangau S. 2007. Konsultasi Kesehatan, Cegah Keputihan. Tabloid Reformata, Edisi 72 Desember Minggu I. Yayasan Pelayanan Media Antiokhia (YAPAMA).

[21] Prawirohardjo S. 2010. Ilmu Kebidanan Sarwono Prawirohardjo. PT Bina Pustaka Sarwono Prawirohardjo, Jakarta.

[22] Riwidikdo H. 2008. Statistika Kesehatan. Nuha Medika, Yogyakarta.

[23] Riyanto A. 2011. Pengolahan dan Analisis Data Kesehatan, Dilengkapi Uji Validitas dan Reliabilitas Serta Aplikasi Program SPSS. Nuha Medika, Yogyakarta

[24] Sahin S; Kevser O; Aleattin U; Dilek A; Tijen N. 2013. An Evaluation of the Relationship between Genital Hygiene Practices, Genital Infection. Gynecology Obstetrics ISSN; 2161-0932.

[25] Sarlito W. 2007. Psikologi Remaja. PT Raja Grafindo Persada, Jakarta.

[26] Setiawan A; Saryono. 2011. Metodologi Penelitian Kesehatan Kebidanan DIII, DIV, S1, S2. Nuha Medika, Yogyakarta.

[27] Shadine M. 2012. Penyakit Wanita Pencegahan, Deteksi Dini dan Pencegahanya. Citra Pustaka, Yogyakarta.

[28] Sugiyono. 2012. Statistika untuk Penelitian. Alfabeta, Bandung.

[29] Sunay D; Kaya E; Ergun Y. 2011. Vaginal Douching Behavior of Women and Relationship Among Vaginal Douching and Vaginal Discharge and Demographic Factors. Journal of Turkish Society of Obstetrics and Gynecology; Vol: 8 Issue: 4 Pages: 264- 71.

[30] Tharpe NL; Cindy LF; Robin GJ. 2016. Clinical Practice Guidelines for Midwifery and Women's Health. Jones \& Bartlett Publishers, Burlington.

[31] Wening S; Lili I;Basuki DH. 2012. Panduan Lengkap Kesehatan Wanita. Penebar PLUS+, Jakarta.

[32] Werner D; Carol T; Jane M. 2010. Apa yang Anda Kerjakan Bila Tidak Ada Dokter, Judul Asli Where There is No Doctor. Andi Offset, Yogyakarta.

[33] Widajaka W; Jannah AW. 2012. Enjoy Your Pregnancy, Mom!. PT Agro Media Pustaka, Jakarta. 